\title{
Number of objectives and conclusions in dissertations and thesis ${ }^{1}$
}

\author{
Número de objetivos e conclusões em dissertações e teses
}

\author{
Richard Eloin Liebano², Sandra Lopes Dias ${ }^{3}$, Lydia Masako Ferreira ${ }^{4}$ \\ 1. Study elaborated in Post-graduation Program in Reconstructive Plastic Surgery - Federal University of São Paulo - Paulista School of \\ Medicine (UNIFESP-EPM). Brazil. \\ 2. Doctor in Sciences by the Post-graduation Program in Reconstructive Plastic Surgery in Federal University of São Paulo - Paulista School \\ of Medicine (UNIFESP-EPM). Brazil. \\ 3. Physical Therapy student in Paulista University (UNIP). \\ 4. Head of Plastic Surgery Division of Surgery Department and Coordinator of Post-graduation Program in Reconstructive Plastic Surgery \\ - UNIFESP - EPM. Brazil
}

\begin{abstract}
Purpose: To analyze the number of objectives and conclusions presented in dissertations and thesis defended at Federal University of São Paulo - Paulista School of Medicine (UNIFESP - EPM). Methods: It was realized a search in the master degree dissertations and doctor degree thesis defended at Federal University of São Paulo - Paulista School of Medicine in the years 2002 and 2003 that were found available in the central library of this university. Results: From 723 master dissertations analyzed, 62 (8,57\%) presented only one objective and one conclusion, 134 (18,53\%) presented one objective and more than one conclusion and 527 (72,89\%) had more than one objective and more than one conclusion. From 502 doctor thesis analyzed, 23 (4,58\%) presented only one objective and one conclusion, 123 (24,50\%) presented one objective and more than one conclusion and 376 (74,90\%) had more than one objective and more than one conclusion.. Conclusions: It wasn't found in researched literature the number of objectives and conclusions a scientific work must have. A highest number of thesis and dissertations presented more than one objective and more than one conclusion.
\end{abstract}

Key words: Theses. Academic Dissertations. Methods.

\section{RESUMO}

Objetivo: Analisar o número de objetivos e conclusões em teses e dissertações defendidas na Universidade Federal de São Paulo - Escola Paulista de Medicina (UNIFESP - EPM), em relação ao número de objetivos e conclusões que as mesmas apresentam.. Métodos: Foi realizado um levantamento das dissertações de mestrado e teses de doutorado defendidas na Universidade Federal de São Paulo - Escola Paulista de Medicina (UNIFESP - EPM) nos anos de 2002 e 2003, que se encontravam disponíveis na biblioteca central desta universidade. Resultados: Das 723 dissertações de mestrado defendidas na UNIFESP - EPM, 62 (8,57\%) apresentaram apenas um objetivo e uma conclusão; 134 (18,53\%) apresentaram um objetivo e mais de uma conclusão e 527 (72,89\%) possuíam mais de um objetivo e mais de uma conclusão. Das 502 teses de doutorado analisadas, 23 (4,58\%) apresentaram apenas um objetivo e uma conclusão, 123 (24,50\%) apresentaram um objetivo e mais de uma conclusão e 376 (74,90\%) possuíam mais de um objetivo e mais de uma conclusão. Conclusões: Não foi encontrado na literatura pesquisada a quantidade de objetivos e conclusões que um trabalho científico deve conter. A maioria das teses e dissertações defendidas na Universidade Federal de São Paulo - Escola Paulista de Medicina (UNIFESP-EPM) nos anos de 2002 e 2003 apresentou mais de um objetivo e mais de uma conclusão. Descritores: Teses. Dissertações. Objetivos. Conclusões.

\section{Introduction}

The main finality of a scientific work is to communicate the developed process and obtained results in an investigation, directed to a reader or specific target public, depending of the objectives that they were proposed ${ }^{1}$.

The main kinds of scientific works are: synthetic articles for publication in some journal monograph for graduation or post-graduation course conclusion, dissertation to get master degree title or thesis if the objective is to get a doctor title $^{1,2,3,4}$. Every scientific work must obey to international rules imposed for it presentation. They must be originals and contribute not just for knowledge enlargements or understanding of determinate problems, but also to serve for model or to offer subsidy for other works. They can be realized in accordance to primary or secondary information sources and elaborated of several ways, in agreement with the methods and proposed objectives ${ }^{2}$.

The general structure that composes a scientific work is constituted by obligatory elements demanded by 
international rules as well as optional elements, independent of the kind of work that has been realized - monograph, dissertation or thesis ${ }^{2,3}$. The main elements that constitute the structure of a scientific work are: essential elements for work identification (pre-text elements), the text where the content is presented and developed (text elements) and the work's final part (post-text elements), where the references, attachments and appendix are placed ${ }^{1,3,5,6}$.

The work's text where the content is presented and developed has as elements the work's objective and conclusion. The objective is a purpose of an analysis, study and research with the finality of explicit it ${ }^{3}$. It must delimit the reach pretension of the investigation, which aspects must be analyzed, serving in this way as a complement to problem determination ${ }^{1}$, where it can be presented as general objective (subject's general vision or central theme that serves as a conductor wire) or as specific objective (exposes in a restrict way and includes intermediary stages) ${ }^{2,7}$. The conclusion is the research's final point where the steps of the analysis go. The author's conclusions and discoveries must be presented in a logical way, clear and concise, supported in the results and discussion, reaffirming in a resumed form the main idea and other important text aspects, answering to the question and the work objectives $1,2,3,6,7$, 8, 9, 10. The consulted authors $1,2,3,6,7,8,9,10$ define and show the objective and conclusion importance as integrant part to essential elements for a scientific work development, but none of these authors elucidate how many objectives and conclusions a scientific work must present.

In this context, this work had as objective analyze the number of objectives and conclusions presented in dissertations and thesis defended at Federal University of São Paulo - Paulista School of Medicine (UNIFESP - EPM).

\section{Methods}

It was realized a search in the master degree dissertations and doctor degree thesis defended at Federal University of São Paulo - Paulista School of Medicine (UNIFESP - EPM) in the years 2002 and 2003 that were found available in the central library of this university. It was found 1225 thesis and dissertations, where 723 (59,02\%) were of master and 502 (40,98\%) were doctor degree. All of them were analyzed in respect of the objectives and conclusion numbers presented.

\section{Results}

From 723 master dissertations defended at UNIFESP EPM, 62 (8,57\%) presented only one objective and one conclusion, $134(18,53 \%)$ presented one objective and more than one conclusion and 527 (72,89\%) had more than one objective and more than one conclusion.

From 502 doctor thesis analyzed, 23 (4,58\%) presented only one objective and one conclusion, 123 (24,50\%) presented one objective and more than one conclusion and 376 (74,90\%) had more than one objective and more than one conclusion. Following, there are graphs comparing the objective and conclusion number of dissertation and thesis of master and doctor, as well as the individual comparison between them (Figures. 1-3).

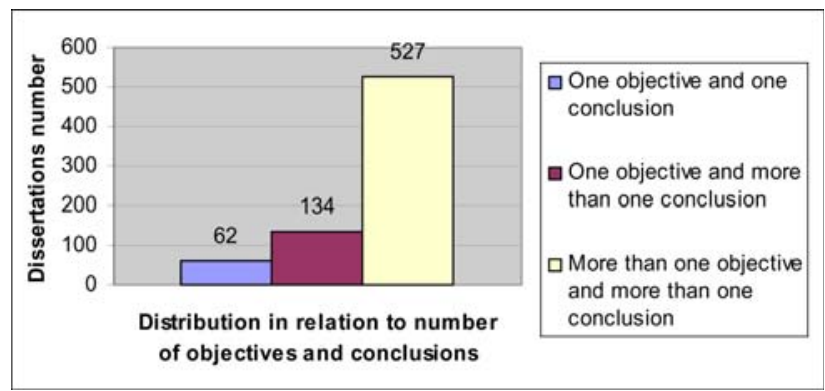

FIGURE 1 - Distribution of master dissertations in relation to number of objectives and conclusions

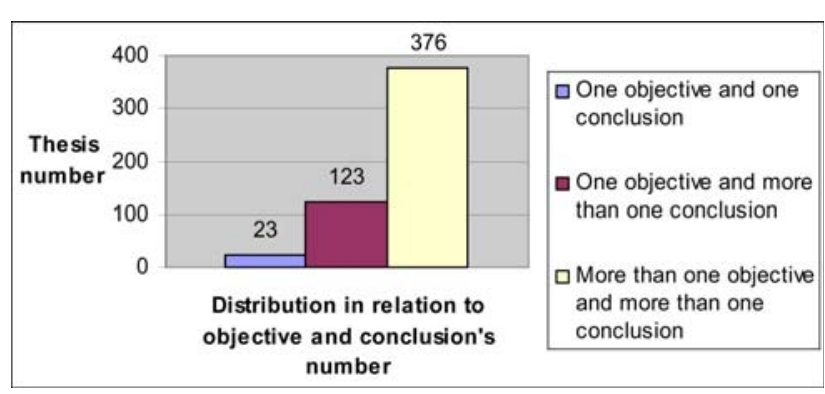

FIGURE 2 - Distribution of doctor thesis in relation to objective and conclusion's number

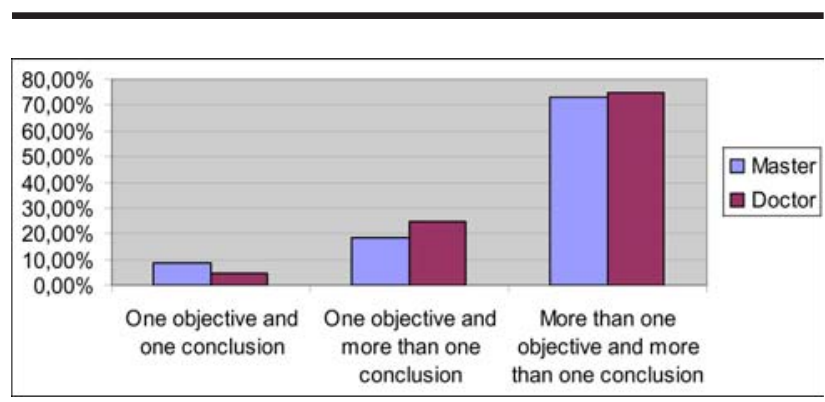

FIGURE 3 - Comparison between master and doctor dissertation and thesis

\section{Discussion}

The scientific work is a method to discovery new knowledges and/or to confirm determined results obtained in different populations. The scientific researches are usually made as monograph for graduation or postgraduation course conclusion, master degree dissertation or doctor and post-doctor thesis. It is extremely important the publication of the study, in order that the obtained information become available to other researches and people interested in the theme.

In a scientific work elaboration there are rules that must be respected in concern of its structural organization and there are differences between the one applied to thesis and monographs from those applied to articles of scientific journals. There are also differences between the rules in different institutions and in different scientific journals. In Brazil, during a long date, researches have used de ABNT (Brazilian Association of Techniques Norms) and, more recently, some research centers and scientific journals of health field have following the International Committee of 
Medical Journals Editors (ICMJE), also known as Vancouver norms, once they were elaborated during a meeting held at this city. In despite of the presence of several norms and published books about scientific methodology ${ }^{1,2,3,7,8}$, they don't mention the number of objectives and conclusions a scientific work must have, giving opportunity for critics by examiners members or professors, based on their scientific experience or self preference.

Due to that, the present study verified the objective and conclusion's number found in dissertations and thesis defended at Federal University of São Paulo - Paulista School of Medicine (UNIFESP - EPM) in the years 2002 and 2003.

After this research, it was possible to observe the small number of works with only one objective and one conclusion (8,57\% master and 4,48\% doctor). It is possible that this reduced number of doctor thesis $(4,48 \%)$ with one objective and one conclusion may be due the fact that doctor works are better elaborated, having a large number of studied variables, allowing a higher conclusion's number. So the advocated exigency that the scientific work must have only one question and one answer wasn't verified in the present study.

As observed in the results, the most of thesis and dissertations presented more than one objective and more than one conclusion.It isn't evaluated in this study if the objectives and conclusions were correct in literary definition.

This kind of study should be realized after. Another kind of work that could be performed is the assessment of the number of objectives and conclusions, dividing the postgraduation programs in accordance to their notes given by Coordination for the Improvement from Superior Level Personnel (CAPES).

\section{Conclusions}

It wasn't found in researched literature the number of objectives and conclusions a scientific work must have.

The highest number of thesis and dissertations defended at Federal University of São Paulo - Paulista School of Medicine (UNIFESP - EPM) - in the years 2002 and 2003 presented more than one objective and more than one conclusion.

\section{References}

1. Koche CJ. Fundamentos de Metodologia Científica - Teoria da Ciência e Iniciação à pesquisa. 21 ed. Rio de Janeiro: Vozes; 2002.

2. Marconi MA, Lakatos EM. Metodologia do Trabalho Científico. 6 ed. São Paulo: Atlas; 2001.

3. Oliveira SL. Tratado de Metodologia Científica. 2 ed. São Paulo: Pioneira Thomson Learning; 2002.

4. Severino AJ. Metodologia do Trabalho Científico. 21 ed. São Paulo: Cortez; 2000.

5. Miranda LH. Metodologia Científica: Caderno de Textos e Técnicas. 7 ed. Rio de Janeiro: Agir; 2001.

6. Rother TE, Braga RM. Como Elaborar sua Tese: Estrutura e Referências. São Paulo; 2001.

7. Parra DF, Almeida JS. Apresentação de Trabalhos Científicos - Monografia, TCC, Teses e Dissertações. 8 ed. São Paulo: Futura; 2001.

8. Ruiz JA. Metodologia Científica: Guia para Eficiência nos Estudos. 5 ed. São Paulo: Atlas; 2002.

9. Ferreira LM, Goldenberg S, Nahas FX, Ely PB. Orientação Normativa para Elaboração e Apresentação de Teses. São Paulo: Ed. CEDCP; 2003.

10. Spector N. Manual para a Redação de Teses, Dissertações e projetos de Pesquisa. 1 ed. Rio de Janeiro: Guanabara Koogan; 1997.

\section{Correspondence:}

Richard Eloin Liebano

UNIFESP-EPM, Plastic Surgery Division, Surgery Division

Rua Napoleão de Barros, 715, $4^{\circ}$ andar

04024-900 São Paulo - SP

Tel: (11)557604118 FAX: (11) 55716579

liebano@gmail.com
Conflict of interest: none Financial source: none

Received: March 3, 2005

Revised: April 19, 2005

Aproved: May 9, 2005

\section{How to cite this article:}

Liebano RE, Dias SL, Ferreira LM. Number of objectives and conclusions in dissertations and thesis. Acta Cir Bras [serial online] 2005 Jul-Aug;20(4). Available from: http://www.scielo.br/acb

* Color figures available from http://www.scielo.br/acb 